\title{
Environmental DNA biomonitoring revealed species diversity of Cnidarian and Poriferan across Jakarta Bay and Seribu Islands National Park
}

Ismail Maqbul ( $\square$ ismailmaqbul@apps.ipb.ac.id)

IPB University Graduate School: Institut Pertanian Bogor Sekolah Pascasarjana https://orcid.org/00000002-3643-4818

\section{Farrahdiba Yossan Fahrezi}

IPB University: Institut Pertanian Bogor

Ersya Nurul A Bakhri

IPB University: Institut Pertanian Bogor

Indri Verawati

IPB: Institut Pertanian Bogor

\section{Lalu M Iqbal Sani}

Oceanogen Environmental Biotechnology Laboklinikum

\section{Beginer Subhan}

IPB: Institut Pertanian Bogor

Neviaty Putri Zamani

IPB University: Institut Pertanian Bogor

Hawis Madduppa

IPB University: Institut Pertanian Bogor https://orcid.org/0000-0003-4260-5625

\section{Research Article}

Keywords: Introduced species, Invasive Species, High throughput sequencing, Species detection, Urban reefs

Posted Date: December 14th, 2021

DOI: https://doi.org/10.21203/rs.3.rs-1167046/v1

License: (c) (i) This work is licensed under a Creative Commons Attribution 4.0 International License.

Read Full License 


\section{Abstract}

Indonesia, as a country having a unique sea lane known as the Indonesian Archipelagic Sea Lanes (ASLs), has become one of the busiest countries in the world with varied shipping activities. These actions have the ability to facilitate the transmission of species (bio-invasion). Until recently, the number of global introduced species has increased, with negative consequences for environment and the economy. Environmental DNA (eDNA) approaches for detecting the presence of invasive species are currently receiving a lot of interest as a broad approach method in ecological research. As a result, the study used the eDNA technique to compare the quantity and variety of introduced species from the Cnidaria and Porifera Phyla, as well as to characterize their invasiveness status and possible presence in the waters of Jakarta Bay. Based on data from the inside Zone of National Park (ZI) and Outside Zone of National Park (ZO), the biological community composition, richness, and diversity were assessed (ZO). The mBrave workflow generated a total of 14,275 reads from high-throughput sequencing of amplicons from two zones, with 8,917 reads in ZI and 5,358 reads in ZO. Blackfordia virginica, Cordylophora caspia , and Ectopleura crocea were among the imported species included in the invasive category, with E. crocea having the highest abundance and being detected in both zones, with a total of 1300 reads, consisting of 1253 reads in $\mathrm{ZI}$ and 47 reads in ZO. Based on the findings, the eDNA methodology can be used as a biomonitoring and conservation method for invasive species.

\section{Introduction}

Indonesia has a unique sea lane known as the Indonesian Archipelagic Sea Lanes (ASLs) and has become one of the busiest countries in the world with varied shipping activities. Many shipping channels, both domestic and international, exist in Indonesian waterways for a variety of reasons, including passenger transit and trade. Through biofouling or ballast water disposal, these operations have the ability to spread species (bio-invasion) (Ruiz et al. 1997). This is inescapable, as people are able to transport numerous organisms from one region to another by moving around aboard ships, whether intentionally or unintentionally (Bax et al. 2003).

Various studies have revealed that many introduced species can develop into invasive species and until now their numbers are still increasing (Bax et al. 2003; Ojaveer et al. 2018; Seebens et al. 2017). Terpios hoshinota, Monanchora clathrata and Petrosia ficiformis are sponges that have become invasive because they attack coral reef in Indonesia by competing for habitat (Huhn et al. 2020; Madduppa et al. 2017; Utami et al. 2018). Besides sponges, another invasive species derives from the Mollusca phylum, such as Perna viridis, which is commonly discovered in Jakarta Bay (Huhn et al. 2015). According to Huhn et al. (2020) Caulerpa racemosa and Codium taylorii are seaweed that are thought to be introduced species in Indonesian waters. Moreover, Blackfordia virginica is species of Cnidaria Phylum in which its status has become invasive in some waters, such as America and Asia (Kimber 2014).

The effects of the presence of invasive species have been paralleled by the damage caused by overfishing, habitat destruction, and changes in water quality (Carlton 2010; Molnar et al. 2008). The 
presence of these organisms in an ecosystem can substitute and degrade the genetic diversity of native species, altering community structures and food webs (Molnar et al. 2008). Additionally, several studies have confirmed that the change of coral reefs into sponges is caused by a response to global warming. Therefore, some sponges take an advantage either directly or indirectly which begins with reproduction (Bell et al. 2013; Powell et al. 2014; Simister et al. 2012a, 2012b). Even more broadly, invasive species can affect the global economy through decreased fisheries production, damage to ship hulls, and blockage of subsea pipelines (Lovell et al. 2006; Ruiz et al. 1997).

A number of countries have implemented prevention of the spread of invasive species through early detection as one of the best strategies for dealing with invasive species (Bax et al. 2003). The common methods that are often used are visual transects and plankton nets. However, this method requires an intensive field survey and the collection of organism specimens directly at the survey site and it is relatively expensive. As an alternative, environmental DNA (eDNA) methods in detecting the existence of invasive species is currently one of the attentions as an extensive approach method in ecological studies (Cristescu and Hebert 2018). A relatively new technique in the field of biodiversity studies has been widely used to identify multi-species scattered in biological substrates such as water and sediments in the form of DNA(Koziol et al. 2019; Taberlet et al. 2012). This method has been established so that it is able to picture the composition of a community from only one sampling, through a metabarcoding process followed by a next-generation sequencing (NGS) process (Huhn et al. 2020; Ruppert et al. 2019). Also, the eDNA method is widely used for detecting invasive species and environmental monitoring to increase accuracy (Clusa et al. 2017; Egan et al. 2013). Additionally, the impact on the environment from the use of eDNA is relatively low (Takahara et al. 2013). For example, the detection of Hypophthalmichthys nobilis and $\mathrm{H}$. Molitrix, which are freshwater fish that invade the Mississippi River (Amberg et al. 2013), and most recently by Holman et al. (2019) spotted introduced and local species in British waters.

As one of the busiest ports in Indonesia, which is located in Jakarta Bay, more than $50 \%$ of all incoming and outgoing goods flows to Indonesia pass through the Tanjung Priok Port. Therefore, this port is used as a barometer of the Indonesian economy. As well, the waters of Thousand Islands, a National Conservation Park, are directly linked to Jakarta Bay which is an area traversed by shipping lanes to and from Tanjung Priok Port and sabuk nusantara ship which is currently still operating in that area. Therefore, these two waters are very vulnerable to bioinvasion. The research aimed to compare the abundance and diversity of introduced species from Cnidaria and Porifera Phyla and to categorize invasiveness status and their potential presence in the waters of Jakarta Bay using eDNA technique.

\section{Materials And Methods}

\section{Study site and eDNA seawater collection}

This research was conducted at four sites in the Jakarta Bay waters (Fig. 1). These sites were divided into two group based on zone. Inside Zone (ZI) of National Park (Harapan Island and Pramuka Island waters) 
and Outside Zone (ZO) of National Park (Untung Jawa and Tanjung Priok Port waters). All samples were collected in May 2019.

Environmental DNA samples were collected at each site using $4 \mathrm{~L}$ bottles on the water column by using Self-Contained Underwater Breathing Apparatus (SCUBA) ( \pm 5 meters below sea surface). All samples then were filtered using sterile filter paper ( $0.4 \mu \mathrm{m}$ pore size, $47 \mathrm{~mm}$ diameter) (Madduppa et al. 2021; Gelis et al. 2021) and peristaltic pump device (MASTERFLEX number 13-310-662) (Bakker et al. 2017; Deiner et al. 2018). After the process was completed, the filter paper directly was cut into small pieces by sterilized scissors and placed them into a $2 \mathrm{ml}$ cryotube containing $1.5 \mathrm{ml}$ DNA shield (ZymoBIOMICS DNA/RNA shield). All of the instruments used at eDNA sampling was sterilised with a $10 \%$ solution commercial bleach to avoid contamination.

\section{eDNA extraction, library preparation and high throughput sequencing}

The filter paper containing DNA was extracted using DNeasy Blood and Tissue kits, and following the available protocol produced by Qiagen; Venlo, Netherlands (Huhn et al. 2020). A total of 313 base pair (bp) of the mtDNA COI fragment were amplified, considered as suitable combination, to target the sample comprised the forward dgHCOI2198 (5' TAA ACT TCA GGG TGA CCA AAR AAY CA 3') and reverse mICOlintF (5' GGW ACW GGW TGA ACW GTW TAY CCY CC 3') (Leduc et al. 2019; Leray et al. 2013), in the first Polymerase Chain Reaction (PCR) stage. Adaptors were also added to forward and reverse primer. Also, Illumina hangovers were added to the primer sequences. The reaction components in the first PCR were $12.5 \mu \mathrm{l}$ MyTaq HS Redmix (BIOLINE), $1.25 \mu \mathrm{l}$ forward dan reverse primer, $9 \mu \mathrm{lddH} 2 \mathrm{O}, 1 \mu \mathrm{l}$ DNA sample, with total volume $25 \mu \mathrm{l}$. The PCR process used a Thermo Cycler with the following conditions: 95 ${ }^{\circ} \mathrm{C}$ for $5 \mathrm{~min}$, then 35 cycles of $95^{\circ} \mathrm{C}$ for $1 \mathrm{~min}, 48^{\circ} \mathrm{C}$ for $45 \mathrm{~s}$ and $72{ }^{\circ} \mathrm{C}$ for $30 \mathrm{~s}$, and a final elongation at $72{ }^{\circ} \mathrm{C}$ for $10 \mathrm{~min}$ (Leray et al. 2016). After the first PCR stage was complete, quality control was conducted to ensure that DNA samples used qualify of purity, quality and quantity. In the second PCR process, DNA samples were added index as sample identity using the Nextera XT index kit. The second reaction PCR used Kapa HotStart HiFi 2x ReadyMix DNA polymerase (Kapa Biosystems Ltd., London, UK), with the following conditions: $5^{\circ} \mathrm{C}$ for $3 \mathrm{~min}$, then 9 cycles of $95^{\circ} \mathrm{C}$ for $30 \mathrm{~s}, 55^{\circ} \mathrm{C}$ for $30 \mathrm{~s}$ and $72{ }^{\circ} \mathrm{C}$ for $30 \mathrm{~s}$, and a final elongation at $72{ }^{\circ} \mathrm{C}$ for $5 \mathrm{~min}$. All libraries concentration were calculated using a Qubit 2.0 Fluorometer (Life Technologies, Thermo Fisher Scientific, Waltham, MA, USA) and purification were conducted using AMPure XP beads (Beckman Coulter, Indianapolis, IN). The library pool was diluted and denatured according to the Illumina MiSeq library preparation guide. The sequencing was conducted using Illmunia Miseq v2 Kit for 300 bp (Stat et al. 2017).

\section{Bioinformatics using mBRAVE pipeline}

The reads obtained from Illumina sequencing was initially analysed using the Multiplex Barcode Research and Visualization Environment (mBRAVE) online pipeline (www.mbrave.net) with OUT cluster data output (Gelis et al. 2021; Leduc et al. 2019; Ratnasingham and Hebert 2016). The steps carried out by MBRAVE were; removing forward and reverse primer sequence, trimming the $10 \mathrm{bp}$ region at beginning of the reads, filtering the reads that meeting with these criteria to retain those with a length $200 \mathrm{bp}$. 
Paired-end reads that met the filtering criteria were then matched against database in Barcode of Life Data Systems BOLD (www.boldsystems.org) and GeneBank NCBI (www.ncbi.nlm.nih.gov) (>98\% similarity) to determine taxa composition, while the World Register of Introduced Marine Species (www.marinespecies.org) was used to determine invasiveness. Non-target sequences were not used in this study. The composition of taxa in each sample was combined at seven levels, Kingdom, Phylum, Class, Order, Family, Genus and Species. The taxonomic identification results were visualised based on ordo. The relative abundance composition of species was compared between zones.

\section{Data analysis}

All statistical analyses were conducted and visualized in R v 4.0.0. taxonomic identification results by ordo were visualised using barplot. Alpha diversity was used to identify species diversity using Phyloseq package (McMurdie and Holmes 2013), consisting of Chao1 values, abundance-based coverage estimator (ACE), Shannon index ( $\left.H^{\prime}\right)$, and Simpson index (D). The Chao1 values and ACE were used for abundance-based non-parametric estimation while the Shannon and Simpson indices were calculated to determine the diversity and dominance of species in each zone.

\section{Results}

The mBrave workflow generated a total of 14,275 reads from high-throughput sequencing of amplicons from two zones, with 8,917 reads in $\mathrm{ZI}$ and 5,358 reads in ZO (Fig 3). In comparison to ZI, which varied from 159 species (Chao1) to 165 species (ACE), the diversity estimate resulted in a higher score in ZO, which ranged from 190 species (Chao1) to 199 species (ACE) (Fig 2). In ZI, the Simpson Index was 0,94, while in ZO, it was 0.83 . In each zone, a score close to one indicated the presence of species domination. Ectopleura crocea and Plakina trilopha had the highest number of readings in $\mathrm{ZI}$, with 1244 and 1057 reads, respectively. Antennella secundaria and Thyroscyphus ramosus had the most number of reads in ZO, with 1781 and 973 reads, respectively. In both zones, the Shannon index (H') ranged from 2.51 (LTN) to $3.52\left(\mathrm{H}^{\prime}\right)(\mathrm{DTN})$. The results were divided into two categories: medium for ZO and high for ZI.

A total of 39 orders were obtained in both zone with 29 orders each zone (Fig 5). Phylum Cnidaria consisted of 21 orders covering 98 families and 145 genera however phylum Porifera consisted of 19 orders covering 31 families and 35 genera. A total of 15 orders were found in $\mathrm{ZI}$, covering 69 families and 94 genera, while in ZO obtained 17 orders covering 64 families and 90 genera. Meanwhile, the phylum porifera obtained 14 orders covering 20 families and 23 genera, and 13 orders covering 19 families and 20 genera, in $\mathrm{ZI}$ and ZO, respectively.

The relative abundance at the order level, for the phylum cnidaria, anthoathecata was the highest in $\mathrm{ZI}$. Meanwhile, in ZO, the highest abundance was leptothecata. In the phylum porifera, Homosclerophorida and desmacellida were the highest in ZI and ZO, respectively. Species identified as introduced species dominated in each phylum and zone, with an abundance percentage of more than $50 \%$ (Fig 4). The number of reads of introduced species obtained was 6588 and 4716 in $\mathrm{ZI}$ and ZO, respectively. At the phylum level, introduced species from the phylum Cnidaria were more abundant than the phylum 
porifera. The number of introduced species included in the invasive category were Blackfordia virginica, Cordylophora caspia, and Ectopleura crocea, in which E. crocea was the highest abundance and found in both zones, with a total number of 1300 reads, consisting of 1253 reads in $\mathrm{ZI}$ and 47 reads in ZO (Fig 6).

\section{Discussion}

\section{Alpha Diversity and Relative Abundance of eDNA}

Water quality including ecological conditions, chemical oceanography, physical oceanography is one of the factors that cause differences in the number of reads and community composition of eDNA (Holman et al. 2019; Anton et al. 2019). ZO is located in Jakarta Bay which is actively traversed by high-intensity shipping lanes. The consequence of this condition is a decrease in water quality caused by the input of various pollutants originating from these activities (Baum et al. 2015; Kowalchuk et al. 2007; Saito and Doi 2021; Turner et al. 2015). This pollutant is one of the degraders of genetic material in the waters. In addition, the pollutant that enters the waters of Jakarta Bay also comes from the mainland through rivers (Pelling and Blackburn 2013). As a result, this will affect the quality and quantity of genetic material in the eDNA sample and will automatically cause the number of reads obtained (Chícharo et al. 2009; Huhn et al. 2020; Ruppert et al. 2019). Additionally, another factor that degrades DNA in the environment is geographical conditions, in which Jakarta Bay Water is shallow water with an average depth of 15 meters, resulting in the mixing of various nutrients with pollutants and genetic material (Koropitan et al. 2009). Untung Jawa Island, which is located in Jakarta Bay and relatively close to Tanjung Priok Port, also has poor water conditions (Muflih et al. 2015), one of the indicators is heavy metals which have exceeded the seawater quality standard set by the Decree of the State Minister of the Environment Number 51 of 2004 concerning Seawater Quality Standards (Alisa et al. 2020).

On the other hand, ZI represented by Pramuka Island and Untung Jawa Island generally has relatively better water quality, especially from pollutants such as heavy metals (Baum et al. 2015; Rudianto et al. 2019). However, this zone still gains input of pollutants from domestic activities, namely sabuk nusantara Ship which is still operating in the Thousand Islands waters (Baum et al. 2015), but the amount is relatively less than in the ZO. The relatively large distance between ZO and ZI does not have a significant effect on the entry of pollutan from ZO to ZI, because the mass transfer of water from ZO to $\mathrm{ZI}$ by undercurrent is very slow (Koropitan et al. 2009).

The results obtained from this study are different from the research conducted by Huhn et al. (2020), in which the abundance of organisms in the Harbor Area is higher than that of coral reef ecosystems such as in $\mathrm{Zl}$ in this study. According to that paper, in the Harbor area there is a lot of food, especially for filter feeder organisms and also low competition between organisms. However, the water quality and environmental conditions at the location differ from this study, such as the number of ships and types of ships that enter, and the research location has little anthropogenic influence. Research related to chemical and biological processes that affect the production, transportation, and degradation of eDNA, then needs to be conducted for biomonitoring with eDNA. 


\section{Order Composition of eDNA}

Differences in the structure of community composition based on eDNA were caused by various factors, including the type of substrate and the physical and biological characteristics of the identified taxa. According to Koziol et al. (2019), The type of substrate is a crucial factor influencing the biotic composition of the marine environment for analysis using eDNA. Samples originated from sediments are more suitable for identifying benthic macrofauna such as sponges, echinoderms, and cnidarians (Leduc et al. 2019; Turner et al. 2015), as these taxa spend most of their life cycle attached to the substrate. Consequently, the genetic material secreted into the environment will mostly accumulate in the sediments. Nevertheless, due to physical factors that cause sediment to be stirred, the genetic material will be resuspended into the water column (Turner et al. 2015). Meanwhile, nekton and planktonic taxon, will be more identified in the water column, since part of their life cycle is in the water column. Both Cnidarians and sponges are benthic, but some of the life cycles of members of the phylum Cnidaria live freely swimming in waters and planktonic in the medusa phase, such as from the class hydrozoa (jellyfish) (Bryant and Arehart 2019), while sponges are mostly attached to the bottom of the water or benthic (Folkers and Rombouts 2020; Leduc et al. 2019).

There is a fascinating thing about the order composition obtained at the zone level, the number of orders shows the same quantity. The possibility of this event is the occurrence of homogeneity and degradation of eDNA particles in the water column, as in the study conducted by Koziol et al. (2019) and Leduc et al. (2019), showing that the composition of taxa obtained from several locations taken from the water column is homogeneous.

In addition, technical factors such as sampling, sample storage, extraction process and eDNA testing protocol, have some influence (Turner et al. 2015). According to Deiner et al. (2015), for biodiversity biomonitoring using eDNA there are several things that need to be considered to acquire the best results, one of which is the selection of protocols or even a combination of several protocols, such as the process of sampling, screening, extraction, and DNA analysis.

Anthoathecata and leptothecata are two orders of the phylum Cnidaria which belong to the class hydrozoa and have the highest abundance in $\mathrm{ZI}$ and ZO, respectively. Information about this order is still relatively difficult because most members of this species are microscopic (Bryant and Arehart 2019) making it difficult to identify visually. Based on the online database in the Atlas of Living Australia (bie.ala.org.au), the distribution of these two orders is abundant throughout Australian waters, but little information is available on their presence in Indonesia.

From the phylum Porifera, the orders desmacellida and homosclerophorida are the orders with the highest relative abundance in $\mathrm{ZI}$ and ZO, respectively. The distribution of these two orders is still relatively small, especially in Indonesia. Based on the online database at Atlas of Living Australia (bie.ala.org.au), both orders are abundant in Australian waters. The order homosclerophorida in Indonesia is only found in the waters of North Sulawesi, while the order Desmacellida has no information about its existence in 
Indonesia. However, some researchers predict the existence of this order in the Caribbean and Western Indo Pacific including Indonesia (van Soest et al. 2012).

\section{Composition and Distribution of Introduced Species and Their Invasive Potential}

The lack of information regarding the presence of introduced species in Indonesia is one of the limiting factors in identifying their status in Indonesia (Wang et al. 2021). Several studies that have succeeded in identifying them in Indonesia are Huhn et al. (2020, 2015); Utami et al. (2018). The access of introduced species into a new environment will pose a threat to changes in biodiversity, but only a few of the introduced species pose a negative threat (Holman et al. 2019). Introduced species have been spreading both regionally (Huhn et al. 2020) and globally (Molnar et al. 2008). The port as an important component in a voyage, is a key factor for monitoring the presence of introduced species, because it is the centre of distribution of these species.

There were 201 species identified as introduced species and only 3 species whose status had become invasive based on WRiMS. All of these invasive species belong to the phylum Cnidaria, namely Blackfordia virginica, Cordylophora caspia, and Ectopleura crocea. There are no reports of how these three species develop significantly in Indonesia's marine and coastal environments. Ecologically and economically, invasive species causes negative impacts, including competition for food and habitat, habitat modification, hybridization, and biofouling (Wang et al. 2021). Some of them even have more than one impact.

\section{Blacfordia virginica}

B. virginica or known as Black Sea Jellyfish is a very small hydrozoa and has a transparent body, originating from the black sea. This animal has spread in various estuarine waters of the world, such as India, North America, South Africa, and southwest Europe. Recent reports of this animal have been found in the Port of Amsterdam, Netherlands (Faasse and Melchers 2014), in the Gironde Estuary, France (Nowaczyk et al. 2016), and in the Baltic Sea (Jaspers et al. 2018). In general, from several studies that have been carried out, it can be concluded that the spread of these animals is through shipping activities, such as the exchange of ballast water (medusa phase) and biofouling (polyp phase).

The life cycle of these animals is metagenic, i.e by alternation of medusa, which reproduce sexually by releasing eggs and sperm into the water column, and polyps which reproduce asexually. During the medusa phase it has a maximum diameter of $22 \mathrm{~mm}$ (average $10 \mathrm{~mm}$ ), whereas during the polyp phase, one individual can stand up to $0.5 \mathrm{~mm}$ in height (Faasse and Melchers 2014). Due to its small size, the type of food of this animal is small planktonic organisms such as crustaceans and copepods. Currently they are well-known as indecisive predators, which are able to eat invertebrates and fish larvae (Chícharo et al. 2009; Wintzer et al. 2013), and this proves that B. virginica is capable of becoming an invasive species in new environments with its feeding habits. In addition, this animal is able to live in a wide niche, such as tolerance to salinity (3-35 ppt), temperature $\left(16.6-23^{\circ} \mathrm{C}\right)$, and dissolved oxygen $(3.8-6.9 \mathrm{mg} / \mathrm{L})$ (Kimber 2014). 


\section{Cordylophora caspia}

C. caspian is a hydrozoa capable of living in brackish waters and even fresh water. Hydrozoa which does not have a planktonic medusa phase in its life cycle, originates from the Black Sea and currently its distribution has reached various water areas of the world. This animal was first discovered outside its native territory in North America in 1870 on the Schuykill River, Pennsylvania. The others regions are Africa (Egypt and Sudan) (Boulenger 1908; Rzoska 1949), Asia (China) (Roch 1924), Europe (France, Germany, Hungary, Italy, Luxenbereg, Netherlands, Poland, Portugal and Spain) (Ambrogi et al. 1983; Chainho et al. 2015; Conde et al. 2013; Correia et al. 2012; Escot et al. 2003; Gruszka 1999; Marchand 1972; Massard and Geimer 1987; Musko et al. 2008; Roos 1979), North America and South America (Argentina, Chile, Panama, USA) (Deserti et al. 2015; Galea et al. 2007; Jones and Rützler 1975; Richardson and Hammond 2016; Smith et al. 2002; Wintzer et al. 2011), Oceania ( Australia, New Zealand, Tasmania) (Roch 1924). This species has a high tolerance for aquatic environments, such as temperature $\left(8-30^{\circ} \mathrm{C}\right)$, salinity (0-40 ppt) (Folino-Rorem et al. 2009), and lives on hard submerged water substrates such as rock surfaces, shells, timber, and other infrastructure.

C. caspia reproduces both sexually and asexually (fragmentation), in which each colony has only one individual sex. One colony of this hydroids can grow to $5 \mathrm{~cm}$, while one individual can grow to $1 \mathrm{~mm}$ (Folino 2000). One of the characteristics of this species is the menon phase, which is a resting phase as a response to environmental conditions that do not allow it to live, but will regenerate after environmental conditions improve (Folino-Rorem et al. 2009). This species is considered a benthic predator, capturing small prey such as worms, larvae and crustaceans, using nematocysts. Moreover, they also compete with other benthic organisms for substrate (Folino-Rorem et al. 2009). Shipping is thought to be the main vector for spreading of $C$. caspia through ballast water or biofouling processes, as happened in some European waters (Seyer et al. 2017).

\section{Ectopleura crocea}

E. crocea is a species belonging to the class hydrozoa, order Anthoathecata, family Tubularidae, and has the common name pink liver hydroid. This hydroid is small with an average size of $400 \mathrm{~mm}$ and live on colonies attached to the substrate. Individually, shape of this animal is like long stems and have flowerlike features called hydrants. This animal originates from the North Atlantic Ocean and spreads to the Pacific Ocean through biofouling and currently its distribution has reached Australia, New Zealand, the Pacific and Atlantic coasts of America, Europe, the Mediterranean, Japan and Korea (Fitridge and Keough 2013; Kim et al. 2020).

Ecologically, E. crocea is an animal that eats planktonic species such as zooplankton, phytoplankton, diatoms and larvae (Genzano 2005), preying by immobilizing it using tentacles and inserting it into the mouth. Recent research has shown that $E$. crocea is a biofouling species that is a food competitor for mussels in aquaculture, causing a decrease in growth (Fitridge et al. 2012). The interesting thing about the existence of this species in the environment is its function as a food source for other organisms such 
as sea hares, echinoderms, and some fish. Therefore, there is a need for proper monitoring in dealing with the presence of this invasive species in coastal and marine waters, considering that this species dominates in this zone with the highest number of reads.

\section{Conclusions}

eDNA technique was successful in comparing and identifying the diversity and abundance of introduced species from the Cnidarian and Poriferan in Jakarta Bay waters. Moreover, this study proves that eDNA metabarcoding methods can be successfully applied as an invasive species biomonitoring method in tropical marine waters without collecting the specimen directly. Also, eDNA metabarcoding can be an effective tool for conservation and monitoring program.

\section{References}

Alisa CAG, Albirqi P MS, Faizal I. 2020. Kandungan Timbal dan Kadmium pada Air dan Sedimen di Perairan Pulau Untung Jawa, Jakarta. Akuatika Indones. 5(1):21. doi:10.24198/jaki.v5i1.26523.

Amberg JJ, McCalla SG, Miller L, Sorensen P, Gaikowski MP. 2013. Detection of Environmental DNA of Bigheaded Carps in Samples Collected from Selected Locations in the St. Croix River and in the Mississippi River. US Geol. Surv. Open-File Rep. 44p.

Ambrogi R, Bedulli D, Matricardi G, Parisi V, Relini G. 1983. Le macrobenthos de la lagune "Sacca del Canarin" (Delta du Pô). Rapp. La Comm. Int. La Mer Mediterranée 28297-302.

Anton A, Geraldi NR, Lovelock CE, Apostolaki ET, Bennett S, Cebrian J, Krause-Jensen D, Marbà N, Martinetto P, Pandolfi JM, et al. 2019. Global ecological impacts of marine exotic species. Nat. Ecol. Evol. 3(5):787-800. doi:10.1038/s41559-019-0851-0.

Bakker J, Wangensteen OS, Chapman DD, Boussarie G, Buddo D, Guttridge TL, Hertler H, Mouillot D, Vigliola L, Mariani S. 2017. Environmental DNA reveals tropical shark diversity in contrasting levels of anthropogenic impact. Sci. Rep. 7(1):1-12. doi:10.1038/s41598-017-17150-2.

Baum G, Januar HI, Ferse SCA, Kunzmann A. 2015. Local and regional impacts of pollution on coral reefs along the thousand islands north of the megacity Jakarta, Indonesia. PLoS One 10(9):1-26. doi:10.1371/journal.pone.0138271.

Bax N, Williamson A, Aguero M, Gonzalez E, Geeves W. 2003. Marine invasive alien species: a threat to global biodiversity. 27313-323. doi:10.1016/S0308-597X(03)00041-1.

Bell JJ, Davy SK, Jones T, Taylor MW, Webster NS. 2013. Could some coral reefs become sponge reefs as our climate changes? Glob. Chang. Biol. 19(9):2613-2624. doi:10.1111/gcb.12212. 
Boulenger CL. 1908. On the occurrence of the hydroid Cordylophora in Egypt. Ann. Mag. Nat. Hist. 1492493. doi:https://doi.org/10.1080/00222930808692439.

Bryant PJ, Arehart TE. 2019. Diversity and life-cycle analysis of Pacific Ocean zooplankton by videomicroscopy and DNA barcoding: Hydrozoa. PLoS One 14(10):1-22. doi:10.1371/journal.pone.0218848.

Carlton JT. 2010. The Inviolate Sea? Charles Elton and Biological Invasions in the World's Oceans. Fifty Years Invasion Ecol. Leg. Charles Elt. 25-33. doi:10.1002/9781444329988.ch3.

Chainho P, Fernandes A, Amorim A, Avila S., Canning-Clode J, Castro J., Costa A., Costa J., Cruz T, Gollasch S, et al. 2015. Non-indigenous species in Portuguese coastal areas, coastal lagoons, estuaries and islands. Estuar. Coast. Shelf Sci. 167199-211. doi:https://doi.org/ 10.1016/j.ecss.2015.06.019.

Chícharo MA, Leitão T, Range P, Gutierrez C, Morales J, Morais P, Chícharo L. 2009. Alien species in the guadiana estuary (SE-Portugal/SW-Spain): Blackfordia virginica (Cnidaria, Hydrozoa) and Palaemon macrodactylus (Crustacea, Decapoda): Potential impacts and mitigation measures. Aquat. Invasions 4(3):501-506. doi:10.3391/ai.2009.4.3.11.

Clusa L, Miralles L, Basanta A, Escot C, García-Vázquez E. 2017. EDNA For Detection Of Five Highly Invasive Molluscs. A Case Study In Urban Rivers From The Iberian Peninsula.

Conde A, Dominguez J, Novais J., Ramil F. 2013. First record of Cordylophora caspia (Hydrozoa: Cnidaria) in the Tagus Estuary, central Portugal. Mar. Biodivers. Rec. 61-6. doi:https://doi.org/ $10.1017 /$ s1755267213000833.

Correia M., Costa J., Chainho P, Felix P., Chaves M., Medeiros J., Silva G, Azeda C, Tavares P, Costa A, et al. 2012. Inter-annual variations of macrobenthic communities over three decades in a land-locked coastal lagoon (Santo André, SW Portugal). Estuar. Coast. Shelf Sci. 110168-175.

doi:https://doi.org/10.1016/j.ecss. 2012.04.028.

Cristescu ME, Hebert PDN. 2018. Uses and Misuses of Environmental DNA in Biodiversity Science and Conservation. Annu. Rev. Ecol. Evol. Syst. 49(1):209-230. doi:10.1146/annurev-ecolsys-110617-062306.

Deiner K, Walser JC, Mächler E, Altermatt F. 2015. Choice of capture and extraction methods affect detection of freshwater biodiversity from environmental DNA. Biol. Conserv. 183(August 2018):53-63. doi:10.1016/j.biocon.2014.11.018.

Deiner K, Lopez J, Bourne S, Holman LE, Seymour M, Grey EK, Lacoursière-Roussel A, Li Y, Renshaw MA, Pfrender ME, et al. 2018. Optimising the detection of marine taxonomic richness using environmental DNA metabarcoding: The effects of filter material, pore size and extraction method. Metabarcoding and Metagenomics 2(November): doi:10.3897/mbmg.2.28963. 
Deserti J., Escalente A., Acuna F. 2015. New record for the distribution of the colonial hydroid Cordylophora caspia (Pallas, 1771) (Cnidaria: Hydrozoa) in Argentina. Check List 111515. doi:https://doi.org/10.15560/11.1.1515.

Egan SP, Barnes MA, Hwang CT, Mahon AR, Feder JL, Ruggiero ST, Tanner CE, Lodge DM. 2013. Rapid Invasive Species Detection by Combining Environmental DNA with Light Transmission Spectroscopy. Conserv. Lett. 6(6):402-409. doi:10.1111/conl.12017.

Escot C, Basanta A, Cobo F, Gonzales M. 2003. Sobre la presencia de Mytilopsis leucophaeta (Conrad, 1831) (Bivalvia, Dreissenacea, Dreissenidae) en el río Guadalquivir (sur de la Península Ibérica). Graellsia 5991-94. doi:https://doi.org/10.3989/graellsia.2003.v59.i1.227.

Faasse M, Melchers M. 2014. The exotic jellyfish Blackfordia virginica introduced into the Netherlands (Cnidaria: Hydrozoa). Ned. Faun. Meded. 43(March):103-109.

Fitridge I, Keough MJ. 2013. Ruinous resident: The hydroid Ectopleura crocea negatively affects suspended culture of the mussel Mytilus galloprovincialis. Biofouling 29(2):119-131. doi:10.1080/08927014.2012.752465.

Fitridge I, Dempster T, Guenther J, de Nys R. 2012. The impact and control of biofouling in marine aquaculture: A review. Biofouling 28(7):649-669. doi:10.1080/08927014.2012.700478.

Folino-Rorem N., Darling J., Auslio CA. 2009. Genetic analysis reveals multiple cryptic invasive species of the hydrozoan genus Cordylophora. Biol. Invasions 111869-1882. doi:https://doi.org/ 10.1007/s10530008-9365-4.

Folino N. 2000. The freshwater expansion and classification of the colonial hydroid Cordylophora (Phylum Cnidaria, Class Hydrozoa). In Marine Bioinvasions: Proceedings of the First National Conference, January 24-27, 1999., J. Pederson (Ed. by), Cambridge, MA: Massachusetts Institute of Technology Sea Grant College Program, pp. 139-144.

Folkers M, Rombouts T. 2020. Sponges Revealed: A Synthesis of Their Overlooked Ecological Functions Within Aquatic Ecosystems. YOUMARES 9 - Ocean. Our Res. Our Futur. 181-193. doi:10.1007/978-3-03020389-4_9.

Galea H., Häussermann V, Försterra G. 2007. Cnidaria, Hydrozoa: Latitudinal distribution of hydroids along the fjords region of southern Chile, with notes on the world distribution of some species. Check List 3308-320. doi:https://doi.org/10.15560/3.4.308.

Gelis ERE, Kamal MM, Subhan B, Bachtiar I, Sani LMI, Madduppa H. 2021. Environmental biomonitoring of reef fish community structure with eDNA metabarcoding in the Coral Triangle. Environ. Biol. Fishes 104(8):887-903. doi:10.1007/s10641-021-01118-3. 
Gruszka P. 1999. The River Odra estuary as a gateway for alien species immigration to the Baltic Sea basin. Acta Hydrochim. Hydrobiol. 27374-382. doi:https://doi.org/10.1002/(SICI)1521-401X (199911)27:5<374::AID-AHEH374>3.0.C0;2-V.

Holman LE, de Bruyn M, Creer S, Carvalho G, Robidart J, Rius M. 2019. Detection of introduced and resident marine species using environmental DNA metabarcoding of sediment and water. Sci. Rep. 9(1):1-11. doi:10.1038/s41598-019-47899-7.

Huhn M, Zamani NP, Lenz M. 2015. A ferry line facilitates dispersal: Asian green mussels Perna viridis (Linnaeus, 1758) detected in eastern Indonesia. Biolnvasions Rec. 4(1):23-29. doi:10.3391/bir.2015.4.1.04.

Huhn M, Madduppa HH, Khair M, Sabrian A, Irawati Y, Anggraini NP, Wilkinson SP, Simpson T, Iwasaki K, Setiamarga DHE, et al. 2020. Keeping up with introduced marine species at a remote biodiversity hotspot: awareness, training and collaboration across different sectors is key. Biol. Invasions 22(2):749-771. doi:10.1007/s10530-019-02126-2.

Jaspers C, Huwer B, Weiland-Bräuer N, Clemmesen C. 2018. First record of the non-indigenous jellyfish Blackfordia virginica (Mayer, 1910) in the Baltic Sea. Helgol. Mar. Res. 72(1): doi:10.1186/s10152-0180513-7.

Jones M., Rützler K. 1975. Invertebrates of the Upper Chamber, Gatún Locks, Panama Canal, with emphasis on Trochospongilla leidii (Porifera). Mar. Biol. 3357-66. doi:https://doi.org/10.1007/BF00 395001.

Kim P, Yoon TJ, Shin S. 2020. Environmental DNA and specific primers for detecting the invasive species ectopleura crocea (Hydrozoa: Anthoathecata) in seawater samples. Sustain. 12(6): doi:10.3390/su12062360.

Kimber J. 2014. Blackfordia virginica: The Black Sea Jellyfish. 9.

Koropitan AF, Ikeda M, Damar A, Yamanaka Y. 2009. Influences of physical processes on the ecosystem of Jakarta Bay: A coupled physical-ecosystem model experiment. ICES J. Mar. Sci. 66(2):336-348. doi:10.1093/icesjms/fsp011.

Kowalchuk GA, Austin JJ, Gooding PS, Stephen JR. 2007. Chapter 12 Valid Recovery of Nucleic Acid Sequence Information from High Contamination Risk Samples - Ancient DNA and Environmental DNA. Perspect. Bioanal. 2(06):357-371. doi:10.1016/S1871-0069(06)02012-X.

Koziol A, Stat M, Simpson T, Jarman S, DiBattista JD, Harvey ES, Marnane M, McDonald J, Bunce M. 2019. Environmental DNA metabarcoding studies are critically affected by substrate selection. Mol. Ecol. Resour. 19(2):366-376. doi:10.1111/1755-0998.12971. 
Leduc N, Lacoursière-Roussel A, Howland KL, Archambault P, Sevellec M, Normandeau E, Dispas A, Winkler G, McKindsey CW, Simard N, et al. 2019. Comparing eDNA metabarcoding and species collection for documenting Arctic metazoan biodiversity. Environ. DNA 1(4):342-358. doi:10.1002/edn3.35.

Leray M, Yang JY, Meyer CP, Mills SC, Agudelo N, Ranwez V, Boehm JT, Machida RJ. 2013. A new versatile primer set targeting a short fragment of the mitochondrial $\mathrm{COI}$ region for metabarcoding metazoan diversity: Application for characterizing coral reef fish gut contents. Front. Zool. 10(1):1-14. doi:10.1186/1742-9994-10-34.

Leray M, Haenel Q, Bourlat SJ. 2016. Preparation of amplicon libraries for metabarcoding of marine eukaryotes using illumina MiSeq: The adapter ligation method. Methods Mol. Biol. 1452(July):209-218. doi:10.1007/978-1-4939-3774-5_14.

Lovell SJ, Stone SF, Fernandez L. 2006. The economic impacts of aquatic invasive species: A review of the literature. Agric. Resour. Econ. Rev. 35(1):195-208. doi:10.1017/S1068280500010157.

Madduppa H, Cahyani NK, Anggoro AW, Subhan B, Jefri E, Sani LM, Arafat D, Akbar N, Bengen DG. 2021. eDNA metabarcoding illuminates species diversity and composition of three phyla (chordata, mollusca and echinodermata) across Indonesian coral reefs. Biodiversity and Conservation. (11):3087-114.

Madduppa H, Schupp PJ, Faisal MR, Sastria MY, Thoms C. 2017. Persistent outbreaks of the "black disease" sponge Terpios hoshinota in Indonesian coral reefs. Mar. Biodivers. 47(1):149-151. doi:10.1007/s12526-015-0426-5.

Marchand J. 1972. Bionomie benthique de l'estuaire de la Loire I. -Observations sur l'estran maritime de la mer a Cordemais. Rev. Des Trav. I'Institut Des Pêches Marit. 3647-67.

Massard JA, Geimer G. 1987. Note sur la présence de l'Hydrozoaire Cordylophora caspia (Pallas, 1771) dans la moselle Allemande et Luxembourgeoise. Bull. La Société Des Nat. Luxemb. 8775-83.

McMurdie PJ, Holmes S. 2013. Phyloseq: An R Package for Reproducible Interactive Analysis and Graphics of Microbiome Census Data. PLoS One 8(4): doi:10.1371/journal.pone.0061217.

Molnar JL, Gamboa RL, Revenga C, Spalding MD. 2008. Assessing the global threat of invasive species to marine biodiversity. Front. Ecol. Environ. 6(9):485-492. doi:10.1890/070064.

Muflih A, Fahrudin A, Wardiatno Y. 2015. Suitability and Carrying Capacity of Tourism in Tanjung Pasir Coast and Untung Jawa Island. J. IImu Pertan. Indones. 20(2):141-149. doi:10.18343/jipi.20.2.141.

Musko I., Bence M, Balogh C. 2008. Occurrence of a new Ponto-Caspian invasive species, Cordylophora caspia (Pallas, 1771) (Hydrozoa: Clavidae) in Lake Balaton (Hungary). Acta Zool. Acad. Sci. Hungaricae 54169-179. 
Nowaczyk A, David V, Lepage M, Goarant A, De Oliveira É, Sautour B. 2016. Spatial and temporal patterns of occurrence of three alien hydromedusae, Blackfordia virginica (Mayer, 1910), Nemopsis bachei (Agassiz, 1849) and Maeotias marginata (Modeer, 1791), in the Gironde Estuary (France). Aquat. Invasions 11(4):397-409. doi:10.3391/ai.2016.11.4.05.

Ojaveer H, Galil BS, Carlton JT, Alleway H, Goulletquer P, Lehtiniemi M, Marchini A, Miller W, OcchipintiAmbrogi A, Peharda M, et al. 2018. Historical Baselines In Marine Bioinvasions: Implications For Policy And Management.

Pelling M, Blackburn S. 2013. Case stuides: Governing social and environmental transformation in coastal megacities. In Megacities and the Coast: Risk, Resilience and Transformation, Oxon: Routledge, pp. 200-205.

Powell A, Smith DJ, Hepburn LJ, Jones T, Berman J, Jompa J, Bell JJ. 2014. Reduced diversity and high sponge abundance on a sedimented indo-pacific reef system: Implications for future changes in environmental quality. PLoS One 9(1): doi:10.1371/journal.pone.0085253.

Ratnasingham S, Hebert P. 2016. Etat des lieux de la mobilité électrique. Véhicules Électriques Myth. Réalités 355-364. doi:10.1111/j.1471-8286.2006.01678.x.

Richardson D., Hammond C. 2016. Dark false mussel, Mytilopsis leucophaeata (Bivalvia: Dreissenidae), in the Lower West River, New Haven, New Haven County, Connecticut. Bull. Peabody Museum Nat. Hist. 57117-125. doi:https://doi.org/10. 3374/014.057.0202.

Roch F. 1924. Experimentelle untersuchungen an Cordylophora caspia (Pallas) [=lacustris Allman] über die abhängigkeit ihrer geographischen verbreitung und ihrer wuchsformen von den physikalischchemischen bedingungen des umgebenden mediums. Zeitschrift Für Morphol. Und Ökologie Der Tiere 2350-426. doi:https://doi.org/10.1007/BF01254871.

Roos P. 1979. Two-stage life cycle of a Cordylophora population in the Netherlands. Hydrobiologia 62231-239. doi:https://doi.org/10.1007/bf0 0043540.

Rudianto, Putra HMP, Gemasabil MA, Merryanti DP. 2019. Assessing the potential of coastal ecosystems to develop marine tourism in Pramuka Island, the Kepulauan Seribu National Park, Jakarta, Indonesia. IOP Conf. Ser. Earth Environ. Sci. 278(1): doi:10.1088/1755-1315/278/1/012068.

Ruiz GM, Carlton JT, Grosholz ED, Hines AH. 1997. Global invasions of marine and estuarine habitats by non-indigenous species: mechanisms, extent, and consequences. Am. Zool. 37(6):621-632. doi:10.1093/icb/37.6.621.

Ruppert KM, Kline RJ, Rahman MS. 2019. Past, present, and future perspectives of environmental DNA (eDNA) metabarcoding: A systematic review in methods, monitoring, and applications of global eDNA. Glob. Ecol. Conserv. 17e00547. doi:10.1016/j.gecco.2019.e00547. 
Rzoska J. 1949. Cordylophora from the Upper White Nile. Ann. Mag. Nat. Hist. 12558-560. doi:https://doi.org/10.1080/00222934908654005.

Saito T, Doi H. 2021. A Model and Simulation of the Influence of Temperature and Amplicon Length on Environmental DNA Degradation Rates: A Meta-Analysis Approach. Front. Ecol. Evol. 9(March):1-8. doi:10.3389/fevo.2021.623831.

Seebens H, Blackburn TM, Dyer EE, Genovesi P, Hulme PE, Jeschke JM, Pagad S, Pyšek P, Winter M, Arianoutsou M, et al. 2017. No saturation in the accumulation of alien species worldwide. Nat. Commun. 81-9. doi:10.1038/ncomms14435.

Seyer T, Morais P, Amorim K, Leitão F, Martins F, Teodósio MA. 2017. On the presence of the pontocaspian hydrozoan cordylophora caspia (Pallas, 1771) in an Iberian estuary: Highlights on the introduction vectors and invasion routes. Biolnvasions Rec. 6(4):331-337. doi:10.3391/bir.2017.6.4.05.

Simister R, Taylor MW, Tsai P, Fan L, Bruxner TJ, Crowe ML, Webster N. 2012a. Thermal stress responses in the bacterial biosphere of the great barrier reef sponge, rhopaloeides odorabile. Environ. Microbiol. 14(12):3232-3246. doi:10.1111/1462-2920.12010.

Simister R, Taylor MW, Tsai P, Webster N. 2012b. Sponge-Microbe Associations Survive High Nutrients and Temperatures. PLoS One 7(12):21-23. doi:10.1371/journal.pone.0052220.

Smith D., Werle S., Klekowski E. 2002. The rapid colonization and emerging biology of Cordylophora caspia (Pallas, 1771) (Cnidaria: Clavidae) in the Connecticut River. J. Freshw. Ecol. 17423-430. doi:https://doi.org/10.1080/02705060.2002.9663916.

van Soest RWM, Boury-Esnault N, Vacelet J, Dohrmann M, Erpenbeck D, de Voogd NJ, Santodomingo N, Vanhoorne B, Kelly M, Hooper JNA. 2012. Global diversity of sponges (Porifera). PLoS One 7(4): doi:10.1371/journal.pone.0035105.

Stat M, Huggett MJ, Bernasconi R, Dibattista JD, Berry TE, Newman SJ, Harvey ES, Bunce M. 2017. Ecosystem biomonitoring with eDNA: Metabarcoding across the tree of life in a tropical marine environment. Sci. Rep. 7(1):1-11. doi:10.1038/s41598-017-12501-5.

Taberlet P, Coissac E, Pompanon F, Brochmann C, Willerslec E. 2012. Towards next-generation biodiversity assessment using DNA metabarcoding - TABERLET - 2012 - Molecular Ecology - Wiley Online Library. Mol. Ecol. 212045-2050.

Takahara T, Minamoto T, Doi H. 2013. Using Environmental DNA to Estimate the Distribution of an Invasive Fish Species in Ponds. PLoS One 8(2): doi:10.1371/journal.pone.0056584.

Turner CR, Uy KL, Everhart RC. 2015. Fish environmental DNA is more concentrated in aquatic sediments than surface water. Biol. Conserv. 18393-102. doi:10.1016/j.biocon.2014.11.017. 
Utami RT, Zamani NP, Madduppa HH. 2018. Molecular identification, abundance and distribution of the coral-killing sponge Terpios hoshinota in Bengkulu and Seribu islands, Indonesia. Biodiversitas 19(6):2238-2246. doi:10.13057/biodiv/d190632.

Wang H, Xie D, Bowler PA, Zeng Z, Xiong W, Liu C. 2021. Non-indigenous species in marine and coastal habitats of the South China Sea. Sci. Total Environ. 759(xxxx):143465.

doi:10.1016/j.scitotenv.2020.143465.

Wintzer A., Meek M., Moyle P., May B. 2011. Ecological insights into the polyp stage of non-native hydrozoans in the San Francisco Estuary. Aquat. Ecol. 45151-161. doi:https://doi.org/10.1007/s10452010-9343-7.

Wintzer AP, Meek MH, Moyle PB. 2013. Abundance, size, and diel feeding ecology of Blackfordia virginica (Mayer, 1910), a non-native hydrozoan in the lower Napa and Petaluma Rivers, California (USA). Aquat. Invasions 8(2):147-156. doi:10.3391/ai.2013.8.2.03.

\section{Statements \& Declarations}

This research was funded by the Ministry of Research and Technology (Ristek/BRIN) through a grant to Hawis under the assignment 4121/IT3.L1/PN/2019. The authors are grateful to all the institutions and individuals that assisted in the completion of this research. In particular, the authors are grateful to the Marine Science and Technology Diving School (MSTDS) and the Marine Biodiversity and Biosystematics Laboratory (Biodivsi) of IPB University for their support in carrying out this research.

\section{Competing Interests}

The authors have no relevant financial or non-financial interests to disclose.

\section{Author Contributions}

All authors contributed to the study conception and design. Sample Collection, material preparation, data collection and analysis were performed by Ismail Maqbul, Farrahdiba Yossan Fahrezi, Ersya Nurul A Bakhri, Indri Verawati and Lalu M Iqbal Sani. The first draft of the manuscript was led by Ismail Maqbul the writing of the manuscript then edited and improved Hawis Maddupa and Lalu M Iqbal Sani.

\section{Figures}




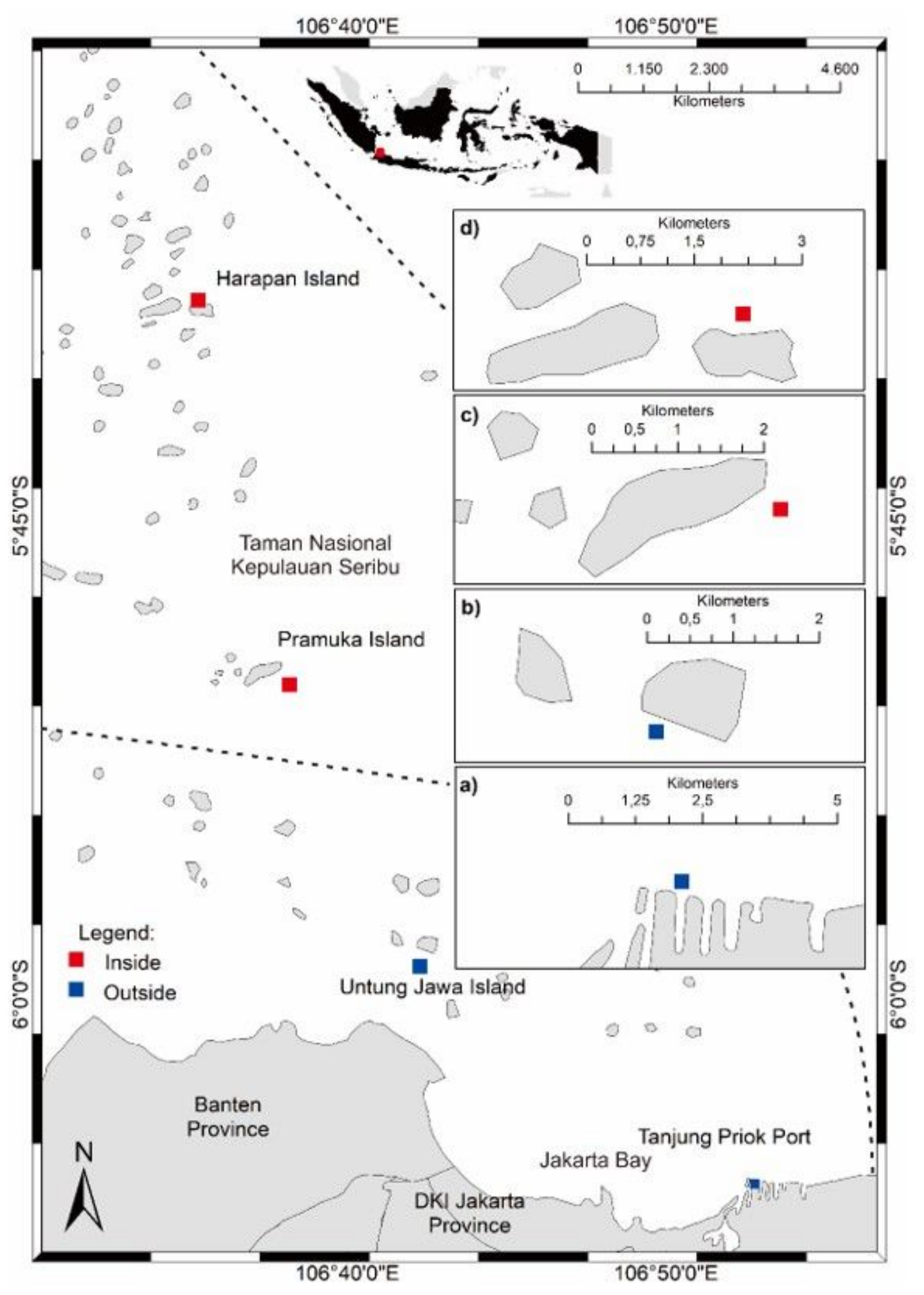

Figure 1

Location of eDNA biomonitoring sampling on Outside National Park of Seribu Island (A) Tanjung Priok Port (B) Untung Jawa Island, and the Inside National Park of Seribu Island (C) Pramuka Island (D) Harapan Island 


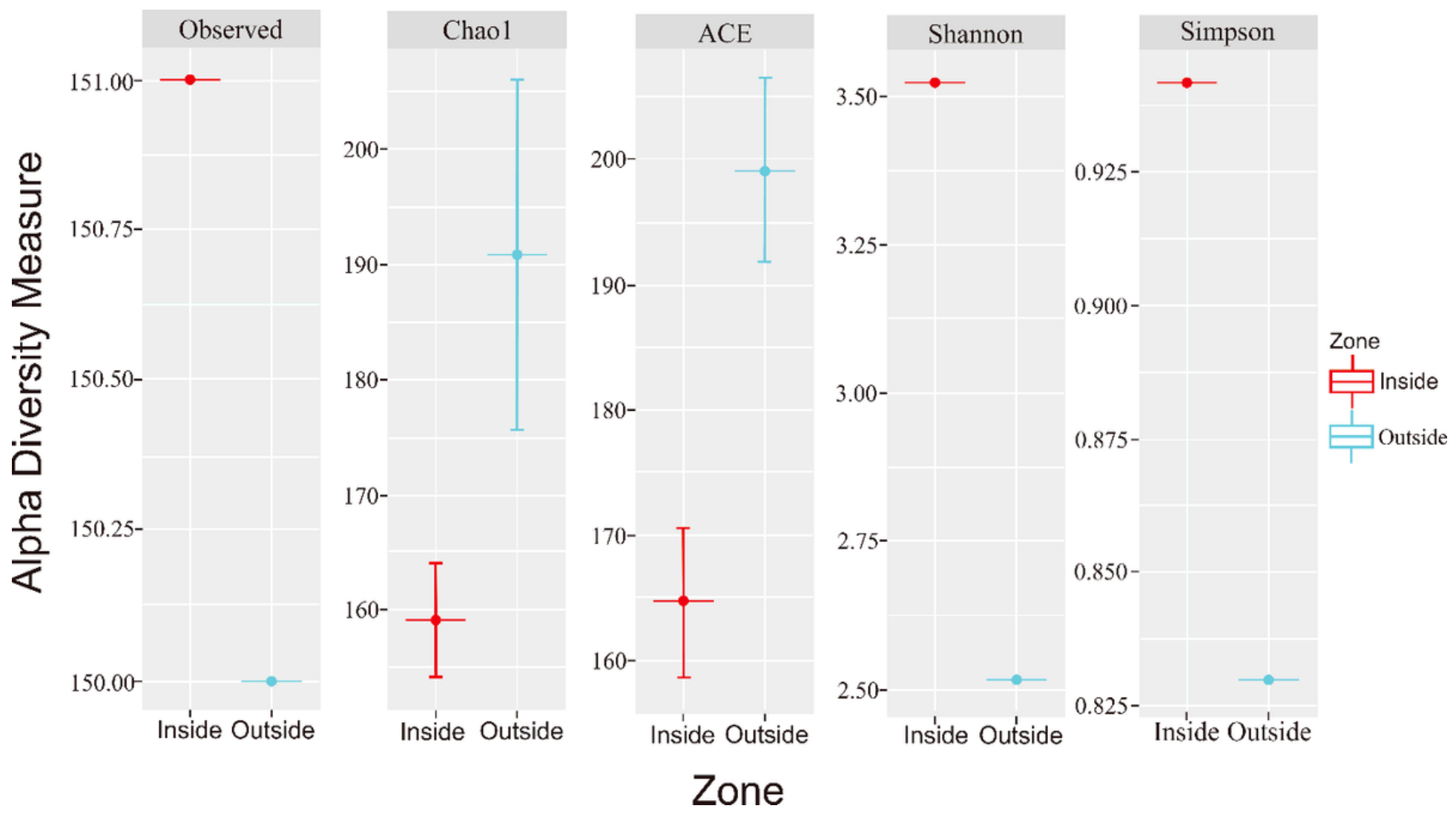

\section{Figure 2}

Alpha diversity boxplot at each zone sampling (Inside National Park and Outside National Park Seribu Islands 


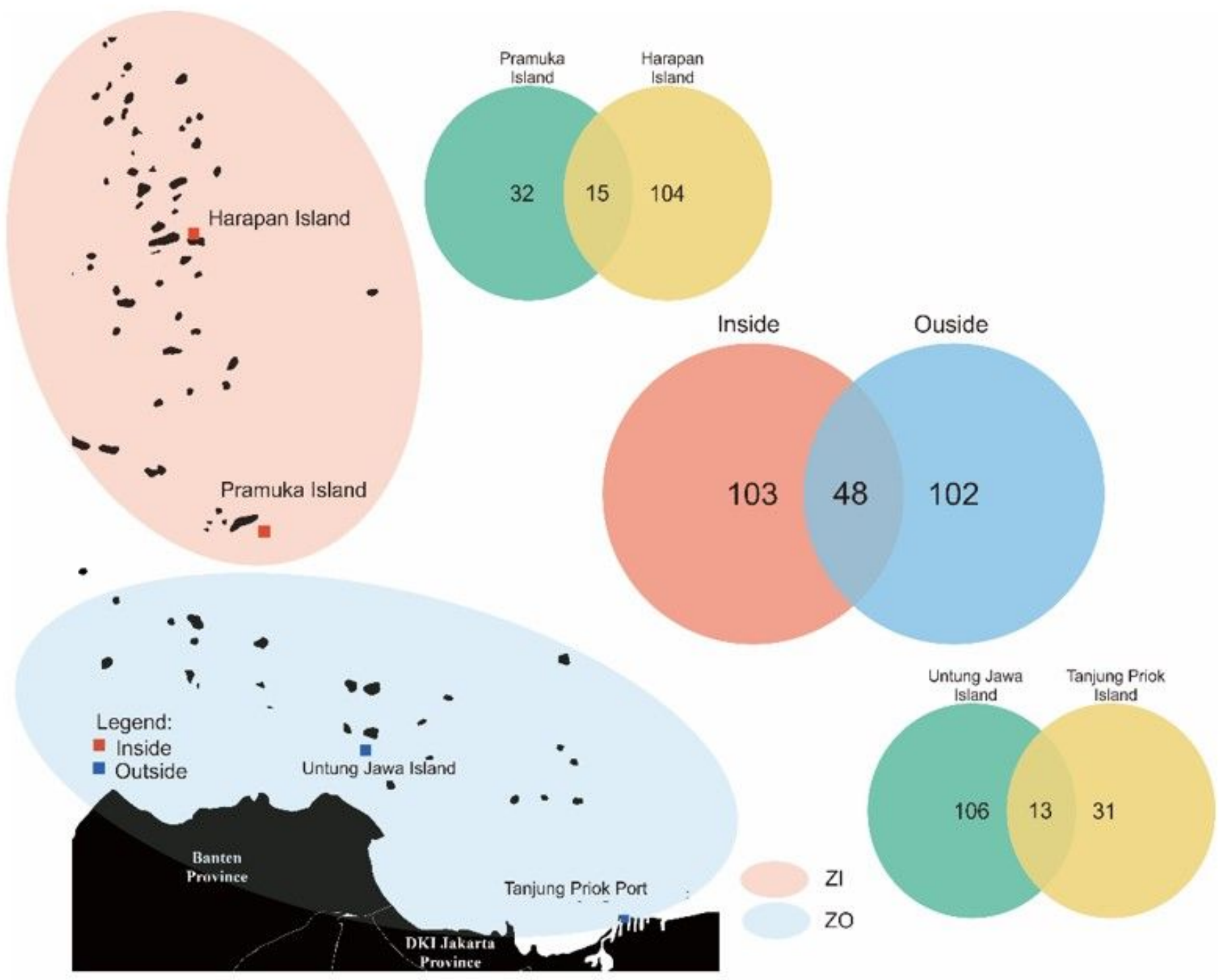

\section{Figure 3}

Venn diagram of species identified in Thousand Islands using eDNA (Inside National Park and Outside National Park Seribu Islands) 


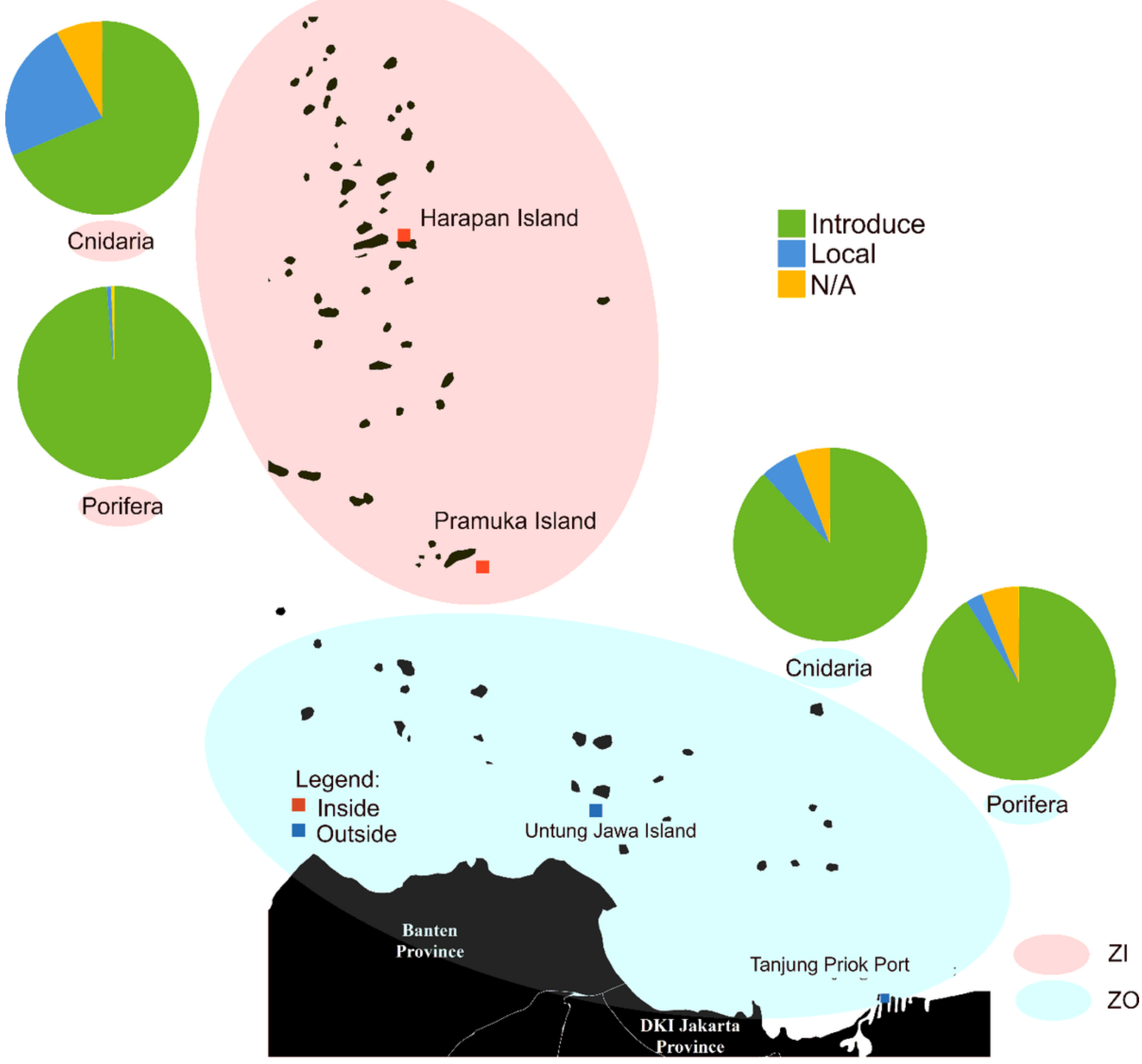

Figure 4

Relative abundance of introduced and local species in the Seribu Islands determined by the zone (ZI: Inside Zone; ZO: Outside Zone) 


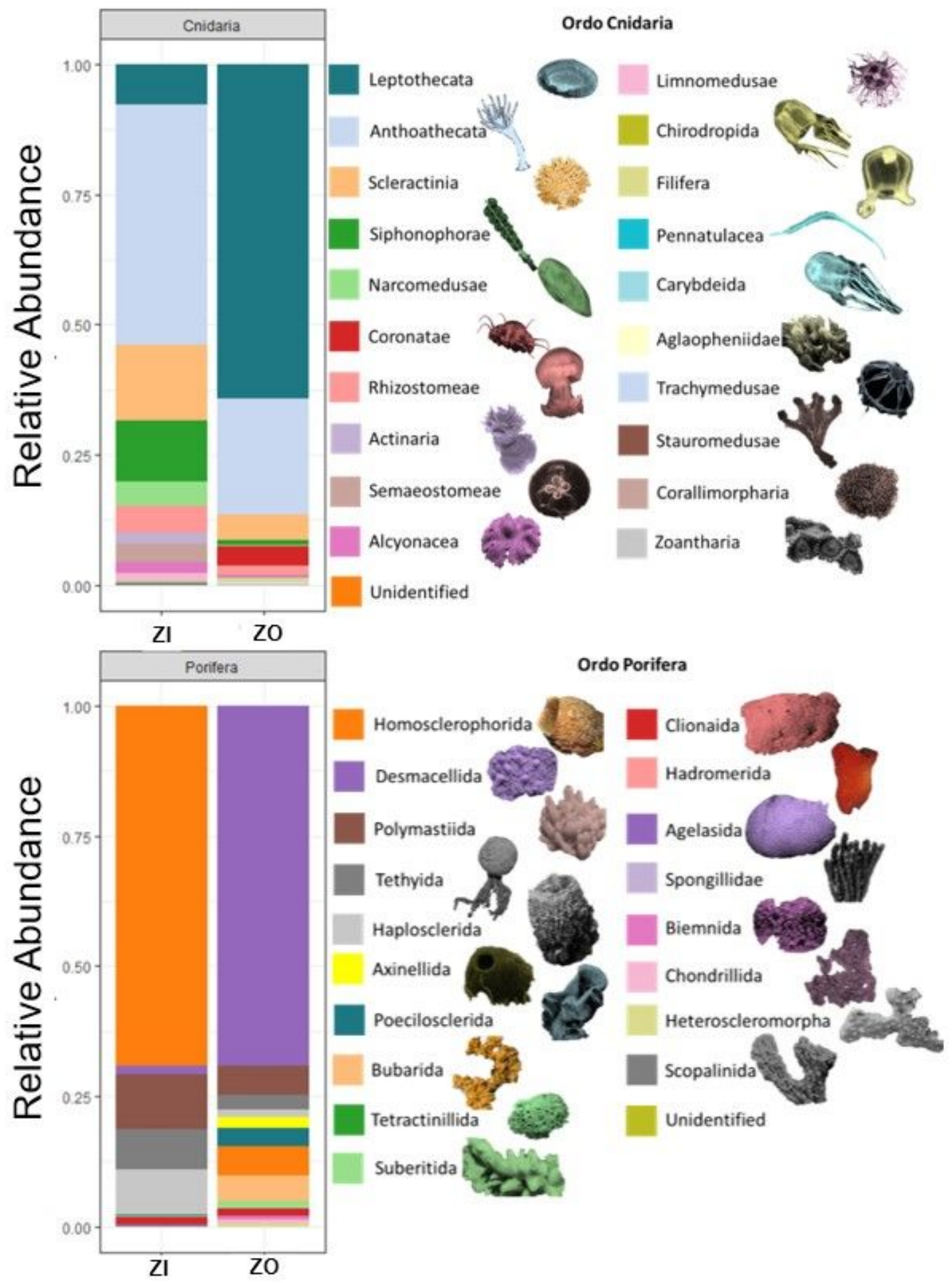

Figure 5

Relative abundance of phyla Cnidaria and Porifera by order level between inside and outside of national park of Seribu Island 


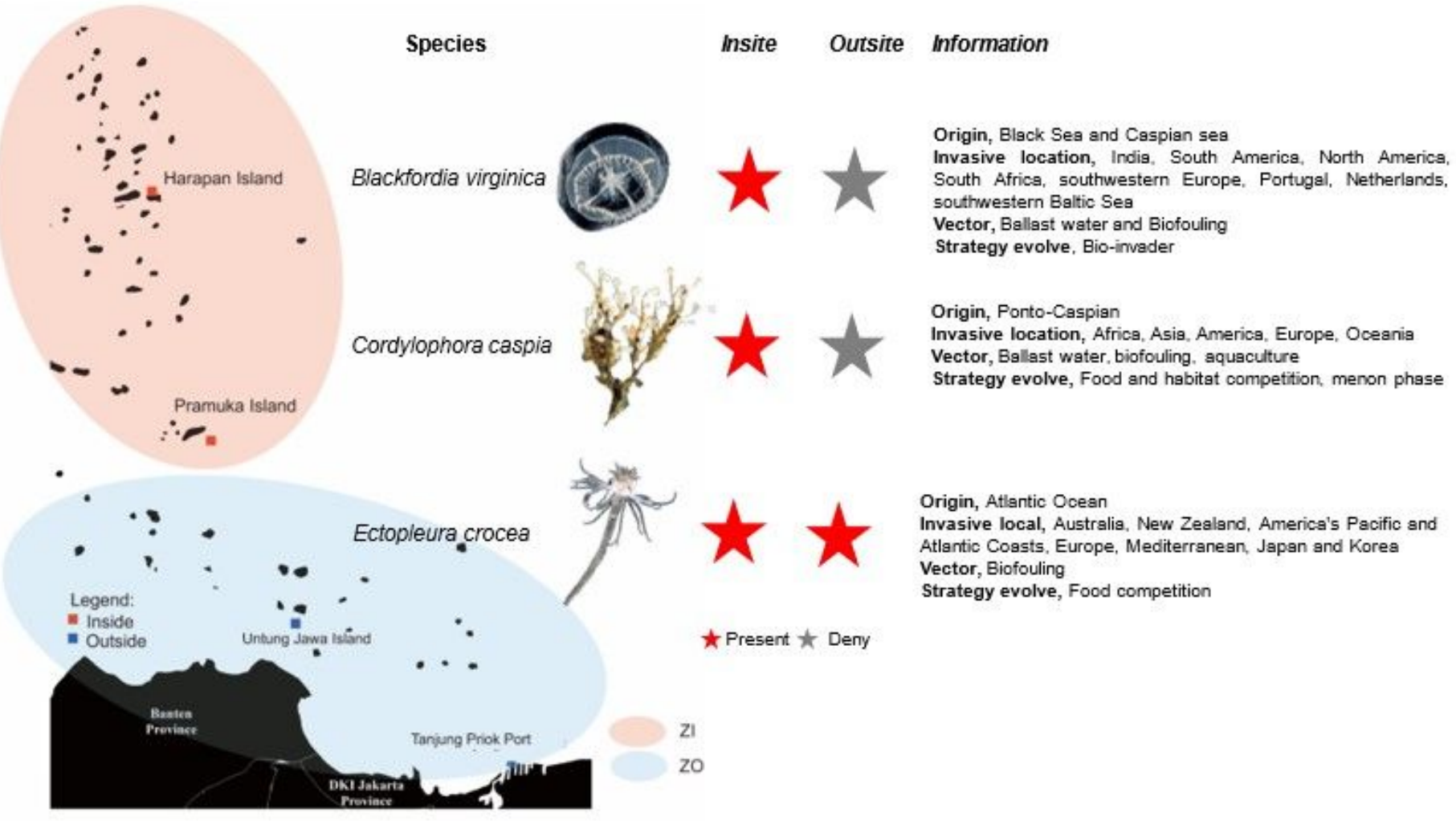

\section{Figure 6}

The presence of invasive species in the Seribu Islands detected by eDNA metabarcoding 